\title{
PENGUASAAN KONSEP SAINS PESERTA DIDIK BERDASARKAN DIMENSI PROSES KOGNITIF DAN DIMENSI PENGETAHUAN
}

\section{MASTERING THE SCIENCE CONCEPT OF STUDENTS BASED ON DIMENSIONS OF COGNITIVE PROCESS AND KNOWLEDGE DIMENSIONS}

\author{
Lalu Tomi Tatma Wijaya, Jamaluddin Jamaluddin*, dan Gito Hadiprayitno \\ Program Studi Pendidikan Biologi FKIP Universitas Mataram, Mataram, Indonesia \\ *Email: jamaluddin.fkip@unram.ac.id
}

Diterima: 4 Juni 2020. Disetujui: 10 Juni 2020. Dipublikasikan: 30 September 2020

\begin{abstract}
Abstrak: Tujuan penelitian ini adalah untuk mengetahui kemampuan peserta didik dalam menguasai konsep sains berdasarkan Taxonomy Bloom's yang telah direvisi oleh Anderson dan Kratwhol, dan penguasaan konsep sains peserta didik dalam dimensi pengetahuan tentang fakta, konsep, dan pengetahuan prosedural. Jenis penelitian ini adalah penelitian deskriptif kualitatif. Populasi penelitian adalah 5917 peserta didik yang tersebar di kelas VIII di 89 SMP Lombok Tengah. Sampel penelitian ditentukan dengan teknik purposive sampling berjumlah 511 peserta didik yang tersebar di 18 kelas. Instrumen penelitian berupa tes pilihan ganda yang terdiri dari 40 item dengan satu jawaban benar dari 4 jawaban alternatif. Analisis data menggunakan rumus persentase untuk menentukan proporsi kemampuan peserta didik dalam menguasai konsep sains. Hasil penelitian menunjukkan bahwa persentase kemampuan peserta didik dalam dimensi proses kognitif adalah kemampuan mengingat (C1) $60.2 \%$, kemampuan memahami (C2) 44.5\%, kemampuan menerapkan (C3) 38.8\%, dan kemampuan untuk menganalisis (C4) $37.2 \%$. Penguasaan konsep sains peserta didik dalam dimensi pengetahuan adalah, pengetahuan faktual $47 \%$, pengetahuan konseptual 43\%, dan pengetahuan prosedural 39\%. Hasil penelitian ini menunjukkan bahwa upaya strategis diperlukan untuk meningkatkan kemampuan peserta didik dalam menguasai konsep sains di sekolah menengah pertama di Kabupaten Lombok Tengah.
\end{abstract}

Kata Kunci: Penguasaan konsep sains, Dimensi Proses Kognitif, Dimensi Pengetahuan

\begin{abstract}
The purpose of this study is to determine students 'abilities in mastering Natural Science concepts based on Bloom's Taxonomy which has been revised by Anderson and Krathwohl, and mastery of students' scientific concepts in the dimension of knowledge about facts, concepts, and procedural knowledge. This type of research is a qualitative descriptive study. The study population was 5917 students spread out in class VIII in 89 junior high schools in Lombok Tengah District. The research sample was determined by a purposive sampling technique totaling 511 students spread across 18 classes. The research instrument was a "multiple choice" test consisting of 40 items with one correct answer from 4 alternative answers. Data analysis uses percentage formulas to determine the proportion of students' abilities in mastering Natural Science concepts. The results showed that the percentage of students' abilities in the dimensions of cognitive processes were the ability to remember (C1) $60.2 \%$, the ability to understand (C2) $44.5 \%$, the ability to apply (C3) $38.8 \%$, and the ability to analyze (C4) $37.2 \%$. Mastery of students' scientific concepts in the dimension of knowledge is, $47 \%$ factual knowledge, $43 \%$ conceptual knowledge, and 39\% procedural knowledge. The results of this study indicate that strategic efforts are needed to improve students' abilities in mastering Natural Science concepts in junior high schools in Lombok Tengah District.
\end{abstract}

Keywords: Mastery of Natural Science Concepts, Cognitive Process Dimensions, Knowledge Dimensions

\section{PENDAHULUAN}

Ilmu Pengetahuan Alam (IPA) berkaitan dengan cara mencari tahu tentang alam secara sistematis, sehingga IPA bukan hanya penguasaan kumpulan pengetahuan yang berupa fakta-fakta, konsep-kensep, atau prinsipprinsip saja tetapi juga merupakan suatu proses penemuan. IPA mencakup dua aspek yaitu body of knowledge sering disebut aspek produk dan proses. IPA sebagai produk atau proses bukan hal terpisah melainkan dua hal yang terjalin erat sebagai kesatuan. Proses IPA menghasilkan pengetahuan yang baru (produk) dan produk IPA memunculkan pertanyaan yang diteliti melalui proses IPA sehingga menghasilkan produk IPA yang lebih baru lagi [1].

Penguasaan konsep merupakan tingkat kemampuan yang mengharapkan peserta didik mampu menguasai/memahami arti atau konsep, situasi dan fakta yang diketahui, serta dapat menjelaskan dengan menggunakan kata-kata sendiri sesuai dengan pengetahuan yang dimilikinya dengan tidak mengubah artinya (Arisanti, 2016). Siswa dapat dikatakan telah menguasai konsep apabila siswa telah mampu (a) berpikir dengan hal tersebut, (b) menggunakannya dalam bidang lain selain yang telah ia pelajari, (c) menyatakannya dengan bahasa atau caranya sendiri, (d) menemukan perumpamaan 
atau analogi tentang hal tersebut,dan (e) membangun model mental maupun fisik mengenai hal tersebut [8].

Nilai rata-rata Ujian Nasional mata pelajaran IPA tahun 2015 adalah $(61,63)$ masih dalam kategori Kurang (D), tahun 2016 nilai rata-rata Ujian Nasional mata pelajaran IPA mengalami penurunan $20 \%$ yaitu $(51,23)$ dengan kategori kurang (D), penurunan terjadi hingga $10 \%$ ditahun 2017 nilai Ujian Nasional rata-rata mata pelajaran IPA yakni $(47,75)$ termasuk kategori kurang (D) data tahun 2018 dan 2019 merupakan pencapaian yangterburuk dalam pelaksanaan Ujian Nasional beberapa tahun terakhir [10].

Secara lebih detail nilai rata-rata Ujian Nasional (UN) tahun 2018 mata pelajaran SAINS SMP di Kabupaten Lombok Tengah adalah 41,42 $\%$ dengan jumlah peserta ujian 6.365 peserta. Hasil ujian nasional pada mata pelajaran SAINS masih dibawah standar nasional. Menurut panduan penilaian oleh satuan pendidikan sekolah menengah pertama (2016), hasil Ujian Nasional mata palajaran sains di kategorikan Kurang. Kemapuan peserta didik di Kabupaten Lombok Tengah di bawah ratarata standar Nasional. Hasil Ujian Nasional SMP Negeri di Kabupaten Lombok Tengah tahun 2018, menunjukkan tingkat penguasaan konsep sains peserta didik belum mencapai kompetensi yang diharapkan. Sebagian besar peserta didik SMP Negeri $(88,6 \%)$ memperoleh hasil UJian Nasional pada mata pelajaran sains $(\leq 64,0)$. Sedangkan $(11,7 \%)$ peserta didik memiliki hasil Ujian Nasional $(\geq 64,1)[10]$.

Menurut Budiati [4], Berdasarkan tinjauan dari dimensi proses kognitif, soal Ujian Nasional sains SMP tahun 2014. Proporsi jumlah soal tingkat mengingat (C1), memahami (C2), menerapkan (C3), menganalisis (C4), mengevaluasi (C5), dan mencipta (C6). Persentase pada stiap tingkatan secara berturut-turtu adalah 10\%, 67.5\%, 10\%, $7.5 \%, 5 \%$, dan tidak terdapat soal pada tingkat C6. Berbeda dengan kemampuan pengetahuan peserta didik dalam bidang sains kelas XI MIA SMA di Kabupaten Enrekang. Pengetahuan tersebut meliputi faktual, konseptual dan prosedural dengan jumlah persentase adalah $56.27 \%, 58.62 \%$ dan $42.69 \%$ [2].

Pengetahuan merupakan hasil belajar kognitif. Hasil belajar pengetahuan yang disusun oleh Bloom saat ini sudah mengalami revisi oleh Anderson \& Krathwohl dibedakan menjadi dua dimensi, yaitu dimensi pengetahuan dan dimensi proses pengetahuan. Dimensi pengetahuan secara garis besar dibedakan menjadi empat kategori yaitu pengetahuan faktual, pengetahuan konseptual, pengetahuan prosedural dan pengetahuan metakognitif [15].

Dimensi proses kognitif, taksonomi yang baru secara umum juga menunjukkan tingkat dari proses pengetahuan yang sederhana ke proses pengetahuan yang lebih kompleks bersifat Fleksibel. Artinya, untuk dapat melakukan proses kognitif yang lebih tinggi tidak mutlak disyaratkan penguasaan proses kognitif yang lebih rendah. Sudut pandang dimensi proses pkognitif menurut Bloom yang telah direvisi oleh Anderson \& Krathwohl dibedakan dalam enam tingkatan yaitu mengingat $(\mathrm{C} 1)$, memahami (C2), menerapkan $(C 3)$, menganalisis $(C 4)$, mengevaluasi (C5), serta mencipta (C6) [14].

Berdasarkan uraian di atas, penelitian ini bertujuan untuk mengetahui Tingkat kemampuan penguasaan konsep sains peserta didik pada dimensi proses kognitif Taksonomi Bloom revisi Anderson dan Kratwhol, dan kemampuan penguasaan konsep sains peserta didik pada dimensi pengetahuan faktual, pengetahuan konseptual, dan pengetahuan prosedural di SMP Negeri Kabupaten Lombok Tengah.

\section{METODE PENELITIAN}

Jenis penelitian ini adalah penelitian deskriptif kualitatif yang mendeskripsikan kemampuan penguasaan konsep sains peserta didik SMP Negeri di Kabupaten Lombok Tengah. Populasi penelitian berjumlah 5917 peserta didik kelas VIII dari 89 SMP Negeri di Kabupaten Lombok Tengah. Sampel penelitian berjumlah 511 peserta didik kelas VIII dari 18 kelas. Teknik penentuan sampel adalah purposive sampling. Penentuan kreteria pertama dalam sampling berdasarkan wilayah yang dikelompokkan menjadi 3 wilayah meliputi utara, tengah dan selatan. Kriteria kedua kemampuan akademik sekolah meliputi akademik tinggi, sedang dan rendah.

Data pada penelitian ini terdiri dari persentase kemampuan peserta didik yang menjawab masing-masing butir soal. Prosedur penelitian ini yaitu penyusunan instrumen soal mengacu pada taksonomi Bloom meliputi C1-C4 dan pengathuan di bidang sains meliputi faktual, konseptual dan prosedural. Berikutnya dilanjutkan dengan pengerjaan soal digunakan untuk mengetahui penguasaan konsep peserta didik. Soal yang digunakan berjumlah 40 butir dengan 4 pilihan jawaban benar.

Analisis data dalam penelitian ini menggunakan statistika deskriptif. Hasil uji ini dapat mengetahui gambaran proporsi penguasaan konsep sains peserta didik. Hasil jawaban soal dianalisis dengan menghitung jumlah jawaban yang benar dari setiap butir soal yang mewakili indikator pencapaian kompetensi dan menghitung masing-masing persentase dari jawaban tersebut. Besarnya persentase dihitung dengan menggunakan rumus [12].

$$
\mathrm{P}=\frac{\mathbf{F}}{\mathbf{N}} \times 100 \%
$$

Keterangan

$P$ : Persentase jawaban

$\mathrm{F}$ : Jumlah total masing-masing jawaban

$\mathrm{N}$ : Jumlah maksimal jawaban 
Persentase jawaban benar akan dikategorikan kedalam kategori kurang, cukup, baik dan sangat baik dengan interval sebagai berikut [7]:

$\begin{array}{ll}>88-100 & : \text { Sangat Baik } \\ >76-88 & \text { : Baik } \\ \geq 64-76 & \text { : Cukup } \\ <64 & \text { : Kurang }\end{array}$

\section{HASIL DAN PEMBAHASAN}

Penelitian ini disusun berdasarkan tujuan penelitian. Bagian pertama menunjukkan hasil tes yang dilakukan pada peserta didik untuk mengetahui penguasaan konsep sains mengacu pada Taksonomi bloom revisi Anderson dan Kratwhol. Bagaian kedua dalam penelitian ini, menunjukkan pengetahuan faktual, konseptual dan prosedural dalam bidang sains. Hasil rata-rata yang diperoleh menggambarkan penguasaan konsep sains baik mengacu pada Taksonomi bloom revisi Anderson dan Kratwhol dan pengetahuan dibidang sains berdasarkan indikator pencapaian kompetensi. Data yang diperoleh dari 18 kelas dianalisis seluruhnya untuk menunjukkan proporsi penguasaan konsep sains peserta didik.

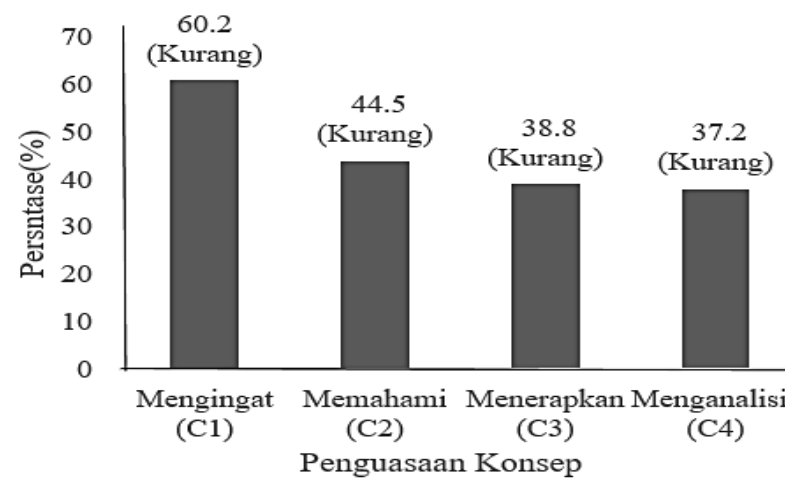

Gambar 1. Penguasaan konsep IPA berdasarkan taksonom Bloom revisi Anderson dan Kratwhol peserta didik SMP Negeri di Kabupaten Lombok Tengah.

Berdasarkan Gambar 1 menunjukkan bahwa penguasaan konsep SAINS peserta didik dengan kategori Kurang. Baik pada kategori mengingat (C1), memahami (C2), menerapkan (C3) maupun menganalisis (C4). Hal tersebut dibuktikan dengan jumlah pesertase kemampuan peserta didik kurang dari dengan kategori kurang. Persentase secara berurutan sebesar $60.2 \%, 44.5 \%, 38.8 \%$ dan $37.2 \%$, sedangkan pada tingkat C5 dan C6 tidak diukur. Hasil ini menunjukkan penguasaan konsep sains peserta didik di Kabupaten Lombok Tengah, semakin tinggi tingkat pengetahuan yang di tagih semakin rendah kemampuan peserta didik.

Penguasaan konsep kategori mengingat (C1), peserta didik dituntut untuk mengingat kembali hal-hal bersifat khusus atau umum, mengingat metode dan proses, mengingat kembali pola atau struktur. misalnya mengenai tanggaltanggal penting, mengenal istilah-istilah dalam sains seperti klorofil, kloning, dan lain-lain [5].

Pada kategori memahami (C2), peserta didik dituntut untuk bisa menyusun makna atau pengertian berdasarkan pengetahuan awal yang dimiliki, mengaitkan informasi yang baru dengan pengetahuan yang telah dimiliki, atau mengintegrasikan pengetahuan yang baru ke dalam skema yang telah ada [3].

Kategori menerapkan (C3), peserta didik harus mampu menggunakan sebuah prosedur dalam situasi yang diberikan. Meliputi penjalanan dan pelaksanaan. Penjalanan atau penerapan yaitu penerapan sebuah prosedur pada tugas yang sudah dikenal (misalnya uji coba larutan asam basa). Pelaksanaan atau penggunaan yaitu penerapan sebuah prosedur pada tugas yang belum atau tidak dikenal (misalnya menerapkan hokum Newton 2 pada situasi yang lain [6]. Sedangkan kategori menganalisis (C4), peserta didik harus mampu memecahkan materi kedalam bagian-bagian kecil dan menunjukkan bagaimana bagian-bagian itu berhubungan satu dengan lainnya dan menjadi struktur menyeluruh atau satu tujuan [13].

Merujuk pada Kompetensi Dasar kelas VII SAINS terdiri dari 11 Kompetensi Dasar, tagihan pada setiap kompetensi sangat berpengaruh pada penguasaan konsep peserta didik. Tingkatan seluruh kompetensi dasar berbeda-beda, terdapat lima (5) KD memiliki tingkatan memahami, satu (1) KD dengan tingkat menerapkan dan lima (5) KD dengan tingkat menganalisis. Berpikir tingkat mengingat (C1), menilai (5) dan mencipta (C6) pada jenjang SMP tidak ada dalam tagihan KD kelas VII SMP.

Dalam panduan penyusunan soal SMP tingkatan $\mathrm{C} 1$ dan $\mathrm{C} 2$ dikategorikan soal mudah, tingkatan C3 merupakan kategori sedang dan tingkat C4, C5, C6 merupakan kategori sulit [9]. Namun, seperti yang diketahui dalam KD kelas VII SMP tingkatan C5 dan C6 tidak ditagih. Berkenaan dengan kurikulum 2013 pembelajaran SAINS disajikan dalam bentuk SAINS terpadu dan ditambah dengan ilmu pengetahuan bumi dan Antariksa, untuk menangih tingkatan C5 dan C6 sangat sulit untuk mengembangkan indikator dalam bentuk terpadu.

Tingkat kesulitan soal akan mengikuti hirarki taksonomi Bloom. Soal kategori mudah akan dikembangkan berdasarkan tingkat kemampuan kognitif mengetahui dan memahami. Soal kategori sedang dikembangkan dari tingkat kemampuan menerapkan dan menganalisis. Sedangkan soal berkategori sukar dikembangkan dari tingkat kemampuan menilai atau mencipta. Bahwa perbandingan soal yang baik untuk kriteria soal mudah, sedang, dan sulit adalah 3:4:3. Berdasarkan perbandingan tersebut persentase soal untuk masing-masing tingkat pengetahuan berdasarkan taksonomi Bloom dirumuskan sebagai berikut, $30 \%$ 
untuk $\mathrm{C} 1$ dan $\mathrm{C} 2,40 \%$ untuk $\mathrm{C} 3$ dan $30 \%$ untuk $\mathrm{C} 4$, C5 dan C6 [11].

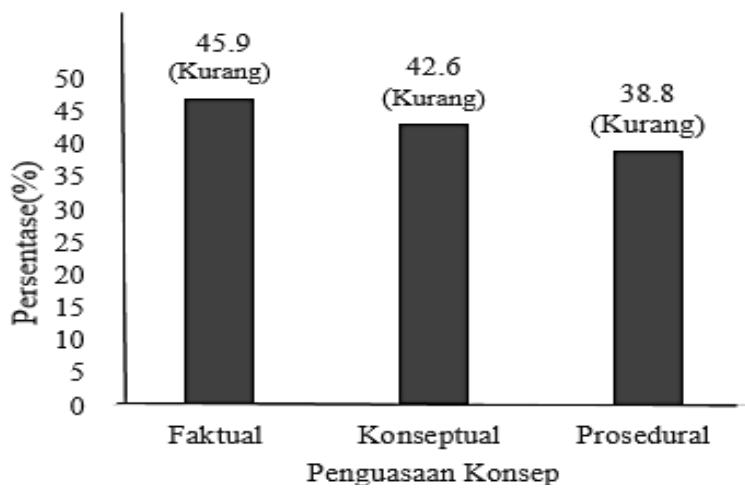

Gambar 2 Dimensi Pengetahuan faktual, koseptual, dan prosedural peserta didik SMP Negeri di Kabupaten Lombok Tengah.

Berdasarkan Gambar 2, diketahui bahwa kemampuan peserta didik SMP Negeri di Kabupaten Lombok Tengah, dikategorikan kurang dalam semua aspek pengetahuan yaitu faktual, konseptual dan prosedural. Pada semua aspek pengetahuan jumlah persesntase yang diperoleh kurang dari (64\%). Hasil rata-rata penguasaan konsep sains berdasarkan pengetahuan faktual, konseptual dan prosedural dalam Bidang sains dikategorikan kurang. Hasil rata-rata pada pengtahuan Faktual, Konseptual dan Prosedural dalam bidang sains dikategorikan Kurang dengan jumlah persentase sebesar $42,4 \%$.

Untuk pengetahuan dalam bidang sains, menunjukkan bahwa kemampuan peserta didik dikategorikan kurang dalam semua pengetahuan yaitu faktual, konseptual dan prosedural. Pengetahuan peserta didik dalam bidang sains hasil persentase tertinggi pada tingkat pengetahuan faktual dengan jumlah persentase sebesar 45,9\% meskipun masih dalam kategori kurang. Hal tersbut kemungkin disebabkan peserta didik pada sekolah menengah baru mengenal terminology yang lebih komplek dan peserta didik kesulitan dalam memahami terminology atau istilah-istilah dalam bahasa ilmiah. Hal inilah yang menyebabkan kemampuan peserta didik dalam penguasaan konsep tidak akan maximal yang akan berimbas pada tingkatan yang lebih tinggi.

Pengetahuan pada tingkat konseptual dalam bidang sains jumlah persentase sebesar (42,6 $\%$ ) dengan kategori kurang dan lebih rendah dari persentase tingkat pengetahuan faktual, dalam pengetahuan konsptual peserta didik dituntut untuk bisa bagaimana suatu materi kajian ditata dan distrukturkan, bagaimana bagian-bagian informasi saling berkaitan secara sistematis, dan bagaimana bagian-bagian ini berfungsi bersama. Pengetahuan konseptual akan baik bila pemahaman pada tingkat pengetahuan Faktual baik.
Pengetahuan dengan hasil terendah dengan kategori kurang adalah pengetahuan pada tingkat Prosedural dengan jumlah persntase sebesar $(38,8 \%)$, artinya untuk bisa pada tahap pengetahuan tingkat prosedural, harus menguasai pengetahuan konseptual. Semua informasi yang disusun secara sistematis dan terstruktur sudah dsainshami akan digunakan dengan bagaimana. Berdasarkan ulasan diatas, penguasaan konsep sains peserta didik SMP Negeri di Kabupaten Lombok Tengah mengalami penurunan pada setiap tingkatan, semakin tinggi tingkatan pengeetahuan yang di ukur penguasaan konsep peserta didik semakin melemah.

Hasil penelitian sebelumnya Assidiq [2] mengungkap, memahami materi pelajaran berupa konsep dari pada materi pelajaran yang sifatnya faktual dan konseptual walaupun kedua dimensi pengetahuan ini berada pada kategori sedang. Secara keseluruhan persentase kemampuan peserta didik untuk pengetahuan prosedural dan metakognitif.

\section{KESIMPULAN}

Berdasarkan hasil dan pembahasan, dapat disimpulkan bahwa Penguasaan konsep sains peserta didik SMP Negeri di Kabupaten Lombok Tengah mengacu pada taksonomi Bloom revisi Anderson dan Kratwhol meliputi kategori mengingat (C1), memahami (C2), menerapakan (C3) dan menganalisis (C4) dengan jumlah persentase $60.2 \%, 44.5 \%, 38.8 \%$. Pengetahuan peserta didik dalam bidang sains yang meliputi pengetahuan faktual, konseptual dan prosedural dengan persentase adalah 47\%, 43\% dan 39\%. Dari kedua hasil analsis, menyatakan kedua aspek yang diukur jumlah persentase kurang dari $64 \%$ dengan kategori kurang. Hal tersebut didasari pada panduan penilain satuan pendidikan tahun 2016 lebih rendah dari persentase kemampuan yang lain, hal ini disebabkan karena guru masih jarang menerapkannya dalam pembelajaran maupun dalam soal-soal. Penyebabkan dalam penguasaan konsep rendah, diantaranya peserta didik tidak memahami materi yang disampaikan guru, peserta didik tidak mempelajari materi kembali materi yang belum dipelajari, peserta yang belajar dari buku catatan yang kurang lengkap dan kesiapan peserta didik kurang maksimal.

\section{DAFTAR PUTAKA}

[1] Andriani, Y., \& Riandi. (2015). Peningkatan Penguasaan Konsep Siswa Melalui Pembelajaran Argument Driven Inquiry pada Pembelajaran IPA Terpadu di SMP Kelas VII. Edusain, 2, 114-120.

[2] Assidiq, I., Sudding, \& Side, S. (2017). Analisis Kemampuan Peserta Didik Kelas XI MIA SMA Di Kabupaten Enrekang Dalam Menyelesaikan Soal-Soal Berdimensi Pengetahuan Faktual, Konseptual, Prosedural dan Metakognitif. Journal Education Chemistry, 1, 91-99. 
[3] Binethara, P., Achmad, A., \& Yolida, B. (2017). Identifikasi UTS dan UAS Mata Pelajaran Biologi Berdasarkan Taksonomi Bloom revisi Anderson. Bioterdidik, 5.

[4] Budiati, H. (2015). Analisis Soal Ujian Nasional Tahun 2013/2014 berdasarkan Dimensi Pengetahuan dan Dimensi Proses Kognitif. Biologi,Sains, Lingkungan dan Pembelajaran, 22, 1199.

[5] Gunawan, I., \& Palupi, A. R. (2012). Taksonomi Bloom Revisi Ranah Kognitif: Kerangka Landasan Untuk Pembelajaran, Pengajaran dan Penilaian. Jurnal Pendidikan Dasar dan Pemebelajaran, 98-116.

[6] Herlanti, Y., \& Nopithalia. (2010). Meneropong Kualitas Soal Tes Buatan Guru Biologi MTs Negeri Se-Jakarta Selatan. Jurnal Penelitian dan Evaluasi Pendidik, 2.

[7] Kemendikbud. (2016). Panduan Penilaian oleh Pendidik dan Satuan Pendidikan.

[8] Konicek, Moran, and Keely, 2015. Teaching for Conceptual Understanding in Science.NSTAPress

[9] Puspendik. (2017). Pandual Penulisan Soal. Jakarta.
[10]Puspendik. (2019). Laporan Hasil Ujian Nasional. diakses dari http://puspendik.kemdikbud.go.id/hasil-un.

[11] Permatasari, I., Ramdani, A., \& Syukur, A. (2019). Pengembangan Bahan Ajar IPA Berbasis Inkuiri Terintegrasi Sets (Science, Environment, Technology And Society) pada Materi Sistem Reproduksi Manusia. Jurnal Pijar Mipa, 14(2), 74-78.

[12] Sugiyono. (2013). Metodelogi Penelitian Pendidikan (Pendekatan Kuantitatif, Kualitatif dan $R \& D)$. Bandung: Alfabeta.

[13] Taufiq, A. U. (2015). Pengembangan Tes Kognitif Berbasis Taksonomi Bloom Pada Materi Sistem Reproduksi Untuk Siswa SMA. Jurnal Biotek, 1-17.

[14] Widodo, A. (2006). Revisi Taksonomi Bloom dan Pengembangan Butir Soal. Journal Pendidikan dan Pembelajaran, 3, 18-29.

[15] Widoretno, S., Sajidan, Ramli, M., \& Ariyanto, J. (2016). Penguasaan Fakta, Konsep, Prosedur dan Metakognitif melalui Pertanyaan Di Pembelajaran Problem Bassed Learning Biologi. Bioedukasi, 9, 18-22. 